\title{
STRATEGI PENGENDALIAN PEMANFAATAN LAHAN DI KAWASAN JALAN KELOK 18 RUAS PARANGTRITIS - GIRIJATI
}

\author{
Bagus Ramadhan \\ Program Studi Perencanaan Wilayah dan Kota, Fakultas Sains dan Teknologi, \\ Universitas AMIKOM Yogyakarta \\ Email : bagusramadhan@amikom.ac.id
}

\begin{abstract}
ABSTRAK
Jalur jalan lintas selatan (JJLS) di Daerah Istimewa Yogyakarta adalah ruas jalan sepanjang 60 kilometer yang dibangun sepanjang pantai selatan DIY. Dalam salah satu ruasnya, yaitu ruas Parangtritis-Girijati, ruas JJLS dibangun di Desa Parangtritis, Kecamatan Kretek, Kabupaten Bantul dan menaiki bukit di sisi timur Desa Parangtritis. Desain jalan ini mengikuti kontur bukit dan direncanakan berkelok sehingga rencana ruas jalan ini disebut sebagai jalan kelok 18. Desa Parangtritis yang terkenal sebagai tujuan wisata dengan beberapa pantainya akan semakin menarik dengan adanya jalan berkelok yang menaiki bukit tersebut. Dari atas bukit atau dari ruas jalan kelok 18 wisatawan dapat melihat bentang alam pantai dan pedesaan sekitar Desa Parangtritis. Dengan adanya rencana jalan kelok 18 dan lokasinya yang berada di kawasan wisata Parangtritis, maka diperlukan pengendalian pemanfaatan lahan untuk mengantisipasi pembangunan di kiri kanan jalan kelok 18 yang dapat mempengaruhi lalu lintas jalan tersebut. Selain itu JJLS sebagai jalan strategis provinsi menyebabkan jalan tersebut perlu memprioritaskan lalu lintas antar kabupaten di DIY. Hasil dari penelitian ini adalah berdasarkan analisis kesesuaian lahan kawasan sekitar jalan kelok 18 sesuai untuk budidaya tanaman tahunan karena kondisi lereng yang agak curam (15-25\%), curah hujan normal dan jenis tanah latosol. Pengendalian pemanfaatan lahan dilakukan dengan distribusi penggunaan lahan menuju kawasan sekitarnya yang tidak berbatasan langsung dengan jalan kelok 18. Distribusi penggunaan lahan dilakukan dengan memfokuskan kawasan penanda keistimewaan yang berada di sekitar jalan kelok 18 sebagai tujuan wisata.
\end{abstract}

Kata Kunci : pengendalian pemanfaatan lahan, kesesuaian lahan, zonasi

\section{A. PENDAHULUAN}

Jalur Jalan Lintas Selatan (JJLS) merupakan jaringan jalan nasional yang melewati DIY di tiga kabupaten yaitu Kabupaten Kulon Progo, Kabupaten Bantul, dan Kabupaten Gunungkidul. Dalam salah satu segmen JJLS melewati Desa Parangtritis, Kecamatan Kretek, Kabupaten Bantul. Pada ruas ParangtritisGirijati atau yang melewati Desa Parangtritis jalur JJLS mulai naik ke Pegunungan Karst Gunungsewu yang menjadi perbatasan antara Kabupaten Bantul dan Kabupaten Gunungkidul. Kondisi saat ini jalur ini belum dibangun, namun desain jalan ini sudah dibuat dan akan didesain dengan desain yang berkelok yang menyerupai jalan kelok 9 di Provinsi Sumatera Barat namun dengan jumlah kelokan yang lebih banyak.

Desa Parangtritis merupakan desa yang mempunyai tujuan wisata skala nasional yaitu Pantai Parangtritis dan kawasan sekitarnya yang menjadi daya tarik 


\section{Bagus Ramadhan, Strategi Pengendalian Pemanfaatan Lahan di Kawasan Jalan Kelok 18 Ruas Parangtritis - Girijati}

bagi wisatawan di setiap akhir pekan maupun musim liburan. Dengan akan dibangunnya akses ke Kabupaten Gunungkidul bagian selatan melalui JJLS dan jalan kelok 18, maka jalan ini akan mempunyai peranan penting dalam pengembangan pariwisata di pantai selatan DIY. Wisatawan dari Pantai Parangtritis dan sekitarnya akan lebih mudah menuju kawasan wisata pantai lainnya di Kabupaten Gunungkidul dengan tersedianya akses JJLS melalui jalan kelok 18 yang menaiki bukit di sisi timur Desa Parangtritis. Potensi wisatawan yang akan menggunakan jalan kelok 18 ini tinggi dan di atas bukit dapat terlihat pemandangan pantai dan beberapa bagian jalan kelok 18 bisa menjadi daya tarik tersendiri bagi wisatawan untuk bisa berhenti di sekitar bagian jalan kelok 18.

Contoh jalan di DIY yang memberikan suguhan pemandangan menarik adalah ruas jalan Yogyakarta-Wonosari di perbatasan Kabupaten Bantul dan Kabupaten Gunungkidul. Pada lokasi yang lebih populer dikenal sebagai kawasan Bukit Bintang ini merupakan bagian jalan berkelok menaiki pegunungan Batur Agung yang menuju ke arah Wonosari, Ibukota Kabupaten Gunungkidul. Pada kawasan bukit bintang ini telah terdapat warung-warung di sepanjang jalan yang memberikan tempat bagi wisatawan untuk melihat pemandangan dari Bukit Bintang. Hal ini menjadi permasalahan karena beberapa warung dibangun dengan konstruksi seadanya pada kontur perbukitan dan tanpa izin. Selain itu beberapa kendaraan yang keluar masuk di warung dapat mengganggu jalan YogyakartaWonosari pada waktu-waktu sibuk seperti akhir pekan dan musim liburan. Beberapa permasalahan inilah yang dikhawatirkan dapat muncul pada jalan kelok 18 di Desa Parangtritis karena di Desa Parangtritis telah menjadi kawasan pariwisata dan jalan kelok 18 menjadi penghubung antar lokasi wisata di Kabupaten Gunungkidul dan Kabupaten Bantul terutama Desa Parangtritis. Perencanaan konstruksi jalan kelok 18 pasti telah mempertimbangkan aspek fisik di kawasan perbukitan Desa Parangtritis, namun apabila tidak ada pengendalian lebih lanjut, warung-warung tanpa izin dapat bermunculan di sepanjang jalan kelok 18 apabila tidak ada pengendalian. Untuk memperkuat pengendalian kawasan ini perlu untuk melakukan analisis kesesuaian lahan untuk kawasan perbukitan di Desa Parangtritis sebagai dasar dalam pengendalian pemanfaatan lahan di jalan kelok 18.

Dengan perkembangan kawasan Desa Parangtritis yang telah menjadi kawasan wisata dan menjadi hub transportasi karena bertemunya jalan Parangtritis sebagai jalan penghubung dengan Kota Yogyakarta di bagian utara dan JJLS yang menuju ke bandara baru Kulon Progo di bagian barat dan tempat wisata di Kabupaten Gunungkidul di bagian timur, maka penggunaan lahan di sekitar jalan kelok 18 yang berada di Desa Parangtritis perlu untuk dikendalikan. Pengendalian ini bertujuan agar penggunaan lahan yang didominasi oleh aktivitas perdagangan yang menyuguhkan pemandangan seperti yang terjadi di Bukit Bintang tidak terjadi pada kawasan jalan kelok 18 ini. Penelitian ini akan melakukan eksplorasi terkait kondisi kemampuan lahan di lokasi rencana trase jalan kelok 18 dan eksplorasi terhadap stakeholder perencanaan dan pengendalian tata ruang baik di dalam Pemerintah Kabupaten Bantul maupun Pemerintah Daerah Daerah Istimewa Yogyakarta karena kawasan jalan kelok 18 ini juga merupakan jalan yang berada di perbatasan antara Kabupaten Bantul dan Kabupaten Gunungkidul. 


\section{Bagus Ramadhan, Strategi Pengendalian Pemanfaatan Lahan di Kawasan Jalan Kelok 18 Ruas Parangtritis - Girijati}

\section{B. TINJAUAN PUSTAKA}

1. Kesesuaian Pemanfaatan Lahan

Dalam memperoleh kelas kesesuaian pemanfaatan lahan diperlukan adanya perbandingan antara tipe penggunaan lahan yang akan diterapkan dengan sifat atau kualitas lahan yang dimiliki oleh lahan yang akan digunakan (Hardjowigeno dan Widiatmaka, 2007). Berdasarkan Permentan Nomor. 837 Tahun 1980 tentang Kriteria dan Tata Cara Penetapan Kawasan Hutan Lindung menyatakan bahwa terdapat tiga parameter dalam penentuan kesesuaian lahan yaitu faktor kelerengan, jenis tanah (kepekaan terhadap erosi) dan intensitas hujan. Adapun kelerengan dibagi menjadi kelas-kelas sebagai berikut :

Tabel 1. Kelas kelerengan sesuai Permentan No.837 Tahun 1980

\begin{tabular}{cll}
\hline No. & Kelerengan & Keterangan \\
\hline 1 & $0 \%-8 \%$ & Datar \\
2 & $8 \%-15 \%$ & Landai \\
3 & $15 \%-25 \%$ & Agak Curam \\
4 & $25 \%-45 \%$ & Curam \\
5 & $45 \%$ atau lebih & Sangat Curam \\
\hline
\end{tabular}

Sumber : Permentan No.837/1980 tentang Kriteria dan Tata Cara Penetapan Kawasan Hutan Lindung

Tabel 2. Kelas jenis tanah sesuai Permentan No.837 Tahun 1980

\begin{tabular}{|c|c|c|}
\hline No. & Jenis Tanah & Keterangan \\
\hline 1 & $\begin{array}{l}\text { Aluvial, Tanah Glei Planosol Hidromof } \\
\text { Kelabu, Literita Air Tanah }\end{array}$ & Tidak peka \\
\hline 2 & Latosol & Agak peka \\
\hline 3 & $\begin{array}{l}\text { Brown Forest Soil, Non Calcis Brown, } \\
\text { Mediteran }\end{array}$ & Kurang peka \\
\hline 4 & Andosol, Laterit, Grumosol, Podosol, Podsolik & Peka \\
\hline 5 & Regosol, Litosol, Organosol, Renzina & Sangat peka \\
\hline
\end{tabular}

Sumber : Permentan No.837/1980 tentang Kriteria dan Tata Cara Penetapan Kawasan Hutan Lindung

Tabel 3. Kelas Jenis Tanah Sesuai Permentan No.837 Tahun 1980

\begin{tabular}{cll}
\hline No. & Curah Hujan & Keterangan \\
\hline 1 & s/d. 13,6 & Sangat rendah \\
2 & $13,6-20,7$ & Rendah \\
3 & $20,7-27,7$ & Sedang \\
4 & $27,7-34,8$ & Tinggi \\
5 & 34,8 keatas & Sangat Tinggi \\
\hline
\end{tabular}

Sumber : Permentan No.837/1980 tentang Kriteria dan Tata Cara Penetapan Kawasan Hutan Lindung

Berdasarkan ketiga parameter di atas maka sejumlah faktor ditentukan masuk dalam kelas tertentu. Berdasarkan kelas masing-masing dilakukan overlay dengan software GIS yang menghasilkan kesesuaian penggunaan lahan pada kawasan yang dituju.

\section{Pengendalian Pemanfaatan Lahan}

Dalam pengendalian pemanfaatan lahan terdapat dua instrumen dalam mengontrol pemanfaatan lahan yaitu rencana tata guna lahan dan zonasi (zoning 


\section{Bagus Ramadhan, Strategi Pengendalian Pemanfaatan Lahan di Kawasan Jalan Kelok 18 Ruas Parangtritis - Girijati}

regulation). Menurut Yin (2012) zonasi adalah regulasi penggunaan lahan yang digunakan oleh pemerintah dalam menentukan penggunaan lahan apa yang sesuai pada suatu lokasi, sedangkan rencana tata guna lahan adalah rencana yang mengantisipasi penggunaan lokasi dan properti di masa depan. Rencana guna lahan merupakan sebuah rencana yang menjadi panduan dalam penggunaan lahan di masa depan dengan menetapkan tujuan yang luas untuk pengembangan di masa depan. Sehingga rencana tata guna lahan lebih fleksibel, sedangkan zonasi merupakan regulasi yang lebih lengkap yang mengatur apa saja kegiatan dan guna lahan yang digunakan dalam suatu lokasi.

Peter Hall (2002) menyatakan bahwa inti dari sistem pengendalian pemanfaatan lahan di Amerika Serikat adalah zonasi. Zonasi di Amerika Serikat terpisah dari perencanaan tata ruang pada umumnya, namun zonasi dibuat oleh komisi zonasi di masing-masing wilayah, sehingga bila tidak perlu maka tidak mengambil muatan dari rencana tata ruang dan pada dasarnya menjadi sistem kontrol yang terbatas dan negatif atas perubahan penggunaan lahan. Zonasi di Amerika Serikat sebenarnya menjadi pembatas antara penggunaan lahan yang seharusnya tidak berdampingan, seperti industri besar dan perumahan dan dengan sifat zonasi yang kaku dan tidak banyak fleksibilitas.

\section{Kebijakan Tata Ruang terkait Zonasi di Indonesia}

Rencana Tata Ruang yang dibuat oleh provinsi dan kabupaten/kota selalu memuat tentang arahan zonasi atau peraturan zonasi. Perbedaannya adalah untuk rencana umum tata ruang atau Rencana Tata Ruang Wilayah (RTRW), memuat zonasi yang masih umum atau arahan zonasi. Sedangkan untuk rencana rinci ada yang telah memuat zonasi sebagai peraturan zonasi yang mengatur secara ketat dan mengatur tiap blok dan ada pula rencana rinci yang masih memuat arahan zonasi. Rencana rinci yang masih memuat arahan zonasi yang merupakan rencana rinci pendetailan dari RTRW Provinsi yaitu Rencana Tata Ruang Kawasan Strategi Provinsi (RTR KSP) karena pada lingkup provinsi yang besar, rencana detailnya berada dalam skala peta antara 1:10.000 hingga 1:25.000. Sedangkan untuk rencana rinci yang mendetailkan Rencana Tata Ruang Wilayah Kabupaten/Kota mempunyai skala peta 1:5.000 sehingga sudah tidak disebut sebagai arahan zonasi namun sudah menjadi peraturan zonasi yang mengatur secara ketat.

Menurut Peraturan Menteri Nomor 37 Tahun 2016 tentang Pedoman Penyusunan Kawasan Strategis Provinsi dan Kawasan Strategis Kabupaten, dalam bagian Arahan Pengendalian Pemanfaatan Ruang Kawasan Strategis Provinsi, arahan peraturan zonasi merupakan salah satu bagian dari arahan pengendalian pemanfaatan ruang Kawasan Strategis Provinsi yang didalamnya juga termasuk arahan perizinan, arahan pemberian insentif dan disinsentif, dan arahan pengenaan sanksi. Dalam penelitian ini lebih memfokuskan pada arahan zonasi dan arahan perizinan di sekitar Rencana Jalan Kelok 18 karena arahan pemberian insentif dan disinsentif dan arahan sanksi merupakan bentuk arahan pengendalian secara administratif.

\section{Status Jalan dan Bagian-Bagian Jalan}

Jalur jalan lintas selatan (JJLS) di pantai selatan DIY diproyeksikan sebagai jalan strategis provinsi. Menurut Peraturan Pemerintah Nomor 34 Tahun 2006 


\section{Bagus Ramadhan, Strategi Pengendalian Pemanfaatan Lahan di Kawasan Jalan Kelok 18 Ruas Parangtritis - Girijati}

tentang Jalan, jalan strategis provinsi merupakan bagian dari jalan kewenangan provinsi. Dalam peraturan tersebut disebutkan bahwa jalan strategis provinsi adalah jalan yang diprioritaskan untuk melayani kepentingan provinsi baik untuk pertumbuhan ekonomi, kesejahteraan dan keamanan provinsi. Hal ini dapat dipahami karena JJLS terletak pada kawasan strategis provinsi (KSP) Pantai Selatan DIY yang menjadi KSP dari sudut kepentingan pertumbuhan ekonomi. Kawasan pantai selatan menjadi kawasan strategis dari sudut kepentingan pertumbuhan ekonomi karena di pantai selatan terdapat pengembangan bandara baru DIY di Kecamatan Temon dan pengembangan pariwisata di sepanjang Pantai Selatan DIY.

Bagian-bagian jalan sendiri dapat dibagi menjadi ruang manfaat jalan, ruang milik jalan dan ruang pengawasan jalan. Ruang manfaat jalan hanya diperuntukan untuk kegiatan yang mendukung fungsi jalan yaitu untuk median, perkerasan jalan, jalur pemisah, bahu jalan, saluran tepi jalan, trotoar, lereng, ambang pengaman, timbunan dan galian, gorong-gorong, perlengkapan jalan, dan bangunan pelengkap lainnya. Sedangkan ruang milik jalan adalah ruang manfaat jalan ditambah sejalur tanah tertentu di luar ruang manfaat jalan. Sejalur tanah tertentu tersebut dapat digunakan sebagai pelebaran jalan dan penambahan jalur. Sejalur tanah tersebut untuk jalan provinsi seperti JJLS adalah 15 meter sesuai ketentuan jalan sedang. Sedangkan ruang pengawasan jalan adalah ruang di luar ruang manfaat jalan dan ruang milik jalan sebagai pandangan bebas pengemudi dan pengamanan.

\section{HASIL DAN PEMBAHASAN}

Penggunaan lahan saat ini pada kawasan jalan kelok 18 didominasi oleh tanaman tahunan dan permukiman. Tanaman tahunan mendominasi pada kawasan dengan topografi perbukitan atau pada kawasan dengan kemiringan lereng antara 15-25\%. Pada beberapa titik dalam kawasan yang digunakan sebagai budidaya tanaman tahunan ini ditemui beberapa warung yang menyuguhkan pemandangan dari atas bukit. Beberapa warung ini menggunakan akses jalan desa dari sebelah utara Desa Parangtritis dan berada di sekitar kawasan Watu Lumbung. Kawasan Watu Lumbung dipenuhi oleh warung-warung karena berada di perbukitan yang bisa melihat pemandangan dan persawahan di bawahnya.
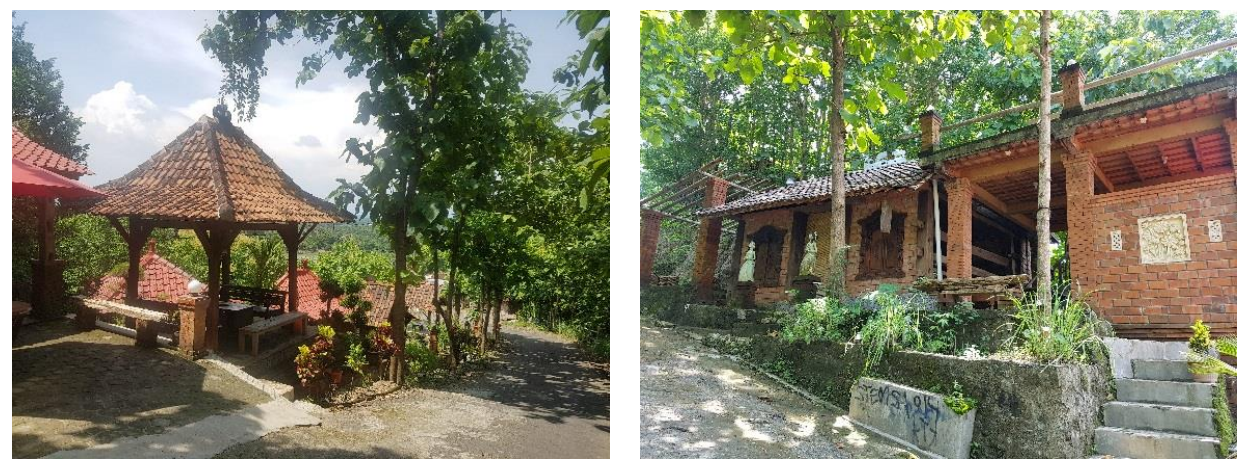

Gambar 2. Beberapa warung di Kawasan Watu Lumbung Sumber : Survey lapangan, 2018 


\section{Bagus Ramadhan, Strategi Pengendalian Pemanfaatan Lahan di Kawasan Jalan Kelok 18 Ruas Parangtritis - Girijati}

Sedangkan kawasan dengan kelerengan di bawah $15 \%$ didominasi oleh penggunaan lahan permukiman pedesaan. Kawasan permukiman pedesaan ini dibatasi oleh topografi yang berbukit sehingga ketika kelerengan kawasan lebih curam warga tidak lagi mengembangkan permukiman ke kawasan tersebut.

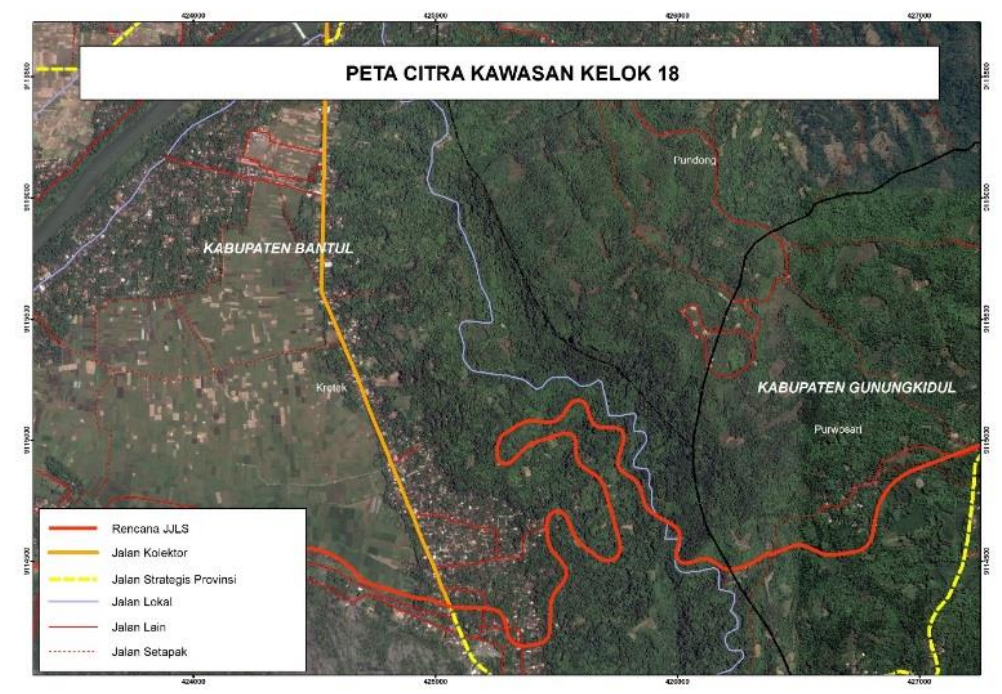

Gambar 3. Peta Citra Rencana Kawasan Jalan Kelok 18 Sumber : Citra Google Earth, 2017

\section{Analisis Kesesuaian Lahan}

Dalam melakukan analisis kesesuaian lahan terdapat tiga parameter yang dijadikan acuan yaitu kelerengan, jenis tanah dan curah hujan. Kelerengan di jalan kelok 18 berada pada kelas kelerengan antara 15\%-25\%. Idealnya dalam membangun bangunan maksimal lereng yang dapat dibangun adalah $15 \%$ (Hardjowigeno dan Widiatmaka, 2011) sedangkan dengan kelas lereng 15\%-25\% sudah tidak ideal untuk membangun bangunan pada kawasan ini terlebih apabila bangunan tidak berizin dan dengan konstruksi yang tidak standar.

Curah hujan di sekitar kawasan jalan kelok 18 adalah seragam dengan curah hujan antara 1000-1500 mm/tahun. Kelas curah hujan ini termasuk dalam kelas curah hujan sangat rendah. Jenis tanah yang berada di rencana kawasan jalan kelok 18 sebagian besar adalah jenis tanah latosol. Tanah latosol mempunyai tekstur lempung sampai geluh, struktur remah sampai gumpal lemah dan konsistensi gembur, warna tanah sedikit merah (Darmawijaya, 1997). Dalam penentuan kelas lereng tanah jenis latosol termasuk tanah yang agak peka atau satu kelas dibawah jenis tanah yang tidak peka sama sekali sehingga tanah jenis latosol tidak terlalu mudah mengalami erosi.

Berdasarkan masing-masing parameter yaitu kelerengan, jenis tanah dan curah hujan kemudian dilakukan analisis kesesuaian lahan sesuai Permentan Nomor 837/1980 tentang kriteria Penetapan Hutan Lindung dengan menggunakan analisis overlay GIS. Adapun hasil dari analisis ini adalah rencana kawasan jalan kelok 18 sesuai untuk kawasan budidaya tanaman tahunan. Kawasan budidaya tanaman tahunan adalah kawasan yang memang bukan berfungsi sebagai kawasan lindung, namun apabila kawasan ini berubah sepenuhnya menjadi kawasan 


\section{Bagus Ramadhan, Strategi Pengendalian Pemanfaatan Lahan di Kawasan Jalan Kelok 18 Ruas Parangtritis - Girijati}

budidaya tanpa adanya tanaman tahunan dikhawatirkan dapat menjadi kawasan dengan kondisi yang tidak ideal sehingga menjadi kawasan yang rawan erosi. Tanaman tahunan pada saat ini telah menjadi penggunaan lahan di rencana kawasan jalan kelok 18.

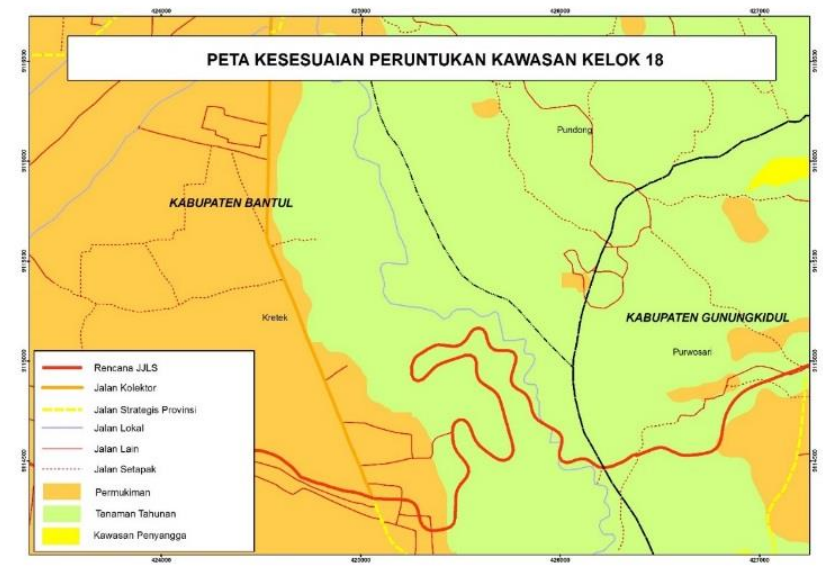

Gambar 4. Peta Kesesuaian Lahan Rencana Kawasan Jalan Kelok 18 Sumber : Analisis, 2017

\section{Kerawanan Bencana}

Pertimbangan dalam menentukan pengembangan atau kesesuaian penggunaan lahan dalam suatu kawasan adalah pertimbangan terhadap kerawanan bencana. Kawasan sekitar rencana jalan kelok 18 pada dasarnya adalah kawasan dengan kelerengan antara 15\%-25\% dan berdasarkan data Kajian Resiko Bencana Indonesia (BNPB, 2016) kawasan tersebut mempunyai tingkat bahaya tinggi bencana longsor. Selain kerawanan terhadap tanah longsor, kawasan sekitar jalan kelok 18 juga mempunyai kerawanan sedang terhadap gempa bumi. Sedangkan kawasan di timur dan barat jalan kelok 18 mempunyai kerawanan tinggi terhadap gempa bumi. Kerawanan gempa bumi ini dikarenakan kawasan jalan kelok 18 merupakan kawasan Sesar Opak yang masih aktif.

\section{Persepsi Stakeholder}

Pengembangan kawasan jalan kelok 18 di kawasan Parangtritis yang juga menjadi kawasan wisata apabila tidak diarahkan dapat berdampak pemanfaatan lahan yang tidak sesuai dengan peruntukannya. Menurut salah satu staf Dinas Pertanahan dan Tata Ruang Kabupaten Bantul rencana kawasan jalan kelok 18 saat ini dalam Rencana Detail Tata Ruang (RDTR) Kawasan Pantai Selatan Bantul masih merupakan zona pertanian lahan kering.

Sedangkan ketika nanti sudah positif dibangun jalan kelok 18 dapat terjadi penyesuaian dalam jalan kelok 18 tersebut karena RDTR Kawasan Pantai Selatan Bantul pada saat ini memang belum disahkan. Ditambahkannya bahwa idealnya kawasan sekitar jalan nasional yang merupakan jalan kelok 18 tersebut seharusnya memang ada zona bebas/buffer sehingga tidak mempengaruhi lalu lintas jalan kelok 18. Namun tidak menutup kemungkinan kawasan sekitar jalan kelok 18 atau di kiri kanan jalan kelok 18 dapat dibangun bangunan dengan adanya studi tertentu atau dengan adanya pembatasan-pembatasan tertentu untuk mengurangi risiko bencana yang mungkin terjadi di kawasan tersebut. 


\section{Bagus Ramadhan, Strategi Pengendalian Pemanfaatan Lahan di Kawasan Jalan Kelok 18 Ruas Parangtritis - Girijati}

"Namanya pinggir jalan pasti ada kegiatan ekonomi, sehingga ya idealnya ada buffer ya. Dengan kajian tertentu bisa (pemanfaatan lahan di kiri kanan jalan kelok 18), dengan kajian tertentu nanti bisa untuk perdagangan dan jasa atau pariwisata nanti boleh." (K- Staf Dinas Pertanahan dan Tata Ruang Kabupaten Bantul, Desember 2017).

Sedangkan menurut salah satu kepala seksi di Dinas Pertanahan dan Tata Ruang DIY pada dasarnya setiap pemanfaatan lahan harus sesuai dengan daya tampung dan daya dukung lahannya. Selain itu Gubernur DIY menetapkan kawasan sekitar jalan kelok 18 sebagai kawasan penanda keistimewaan. Pada kawasan penanda keistimewaan tersebut akan menjadi kawasan terpadu yang dapat menampung berbagai kegiatan pendukung pariwisata di kawasan Parangtritis. Namun meskipun telah ditetapkan sebagai kawasan penanda keistimewaan perlu untuk memperhatikan daya dukung dan daya tampung kawasan tersebut.

"Pemanfaatan ruang disana memang akan menjadi penanda keistimewaan, istilahnya untuk tetenger. Mengapa penanda keistimewaan disitu karena memang kebijakan Bapak Gubernur, mungkin karena visinya menyongsong abad samudera, jadi di kawasan selatan. Sekarang sudah ada trase jalan kelok 18, ketika mau merencanakan peruntukan harus sesuai daya dukung dan daya tampung." (HKepala Seksi di Dinas Pertanahan dan Tata Ruang DIY, Desember 2017)

Kawasan penanda tersebut menurutnya memang seharusnya sebagai kawasan penanda saja, sedangkan di sekitarnya menjadi kawasan non terbangun karena konturnya yang agak curam. Perlu untuk mengendalikan kawasan sekitar kawasan tersebut agar jika kawasan penanda sudah terbangun tidak muncul bangunanbangunan liar yang berada pada kontur agak curam. Sedangkan untuk pemenuhan amenitas wisata bisa berada di sekitar Pantai Parangtritis.

"Saya cenderung kalau disana ya hanya kawasan penanda saja, namun amenitas di Pantai Parangtritis. Namun memang perlu pengendalian, agar kawasan penanda tidak menarik pengembangan lainnya. Kalau wisata harapannya ya kawasan tersebut jangan menjadi wisata masal." (H-Kepala Seksi di Dinas Pertanahan dan Tata Ruang DIY, Desember 2017)

Dengan akan dibangunnya kawasan penanda keistimewaan ini maka penggunaan lahan kegiatan pariwisata atau kegiatan menikmati panorama di atas bukit untuk melihat panorama kawasan Parangtritis dan sekitarnya dapat difokuskan di kawasan penanda keistimewaan ini. Kawasan penanda keistimewaan ini diharapkan dapat sebagai alternatif wisata di kawasan Parangtritis dan dapat lebih banyak menarik wisatawan untuk melihat panorama kawasan Parangtritis daripada berada di kiri kanan jalan kelok 18.

\section{Arahan Zonasi Kawasan Jalan Kelok 18}

Berdasarkan berbagai pertimbangan yang telah disampaikan, pengendalian pemanfaatan lahan di jalan kelok 18 dilakukan dengan arahan zonasi kawasan dan mekanisme disinsentif. Zonasi kawasan dilakukan dengan menetapkan penggunaan lahan di sekitar jalan kelok 18 sehingga menjadi penggunaan lahan yang sesuai dengan kesesuaian lahan dan mengarahkan penggunaan lahan apa saja yang dapat berada di sekitar jalan kelok 18. Pengendalian pemanfaatan lahan 


\section{Bagus Ramadhan, Strategi Pengendalian Pemanfaatan Lahan di Kawasan Jalan Kelok 18 Ruas Parangtritis - Girijati}

lainnya dengan mengembangkan mekanisme disinsentif pada jalan kelok 18 agar pembangunan yang ada pada kawasan tersebut dibatasi akses infrastrukturnya.

Sesuai analisis kesesuaian lahan, kawasan sekitar jalan kelok 18 sesuai untuk penggunaan lahan budidaya tanaman tahunan dimana kawasan tersebut secara umum kurang cocok untuk bangunan. Selain itu terdapat ancaman bencana yaitu tingkat kerawanan tinggi bencana tanah longsor dan tingkat kerawanan sedang bencana gempa bumi. Namun dari kondisi eksisting dan kebijakan daerah, kawasan tersebut berkembang menjadi kawasan wisata dengan sudah mulai banyaknya warung-warung di sekitar kawasan Watu Lumbung dan rencana kawasan terpadu penanda keistimewaan DIY. Sehingga arahan zonasi bagi jalan kelok 18 yang ideal adalah sebagai berikut :

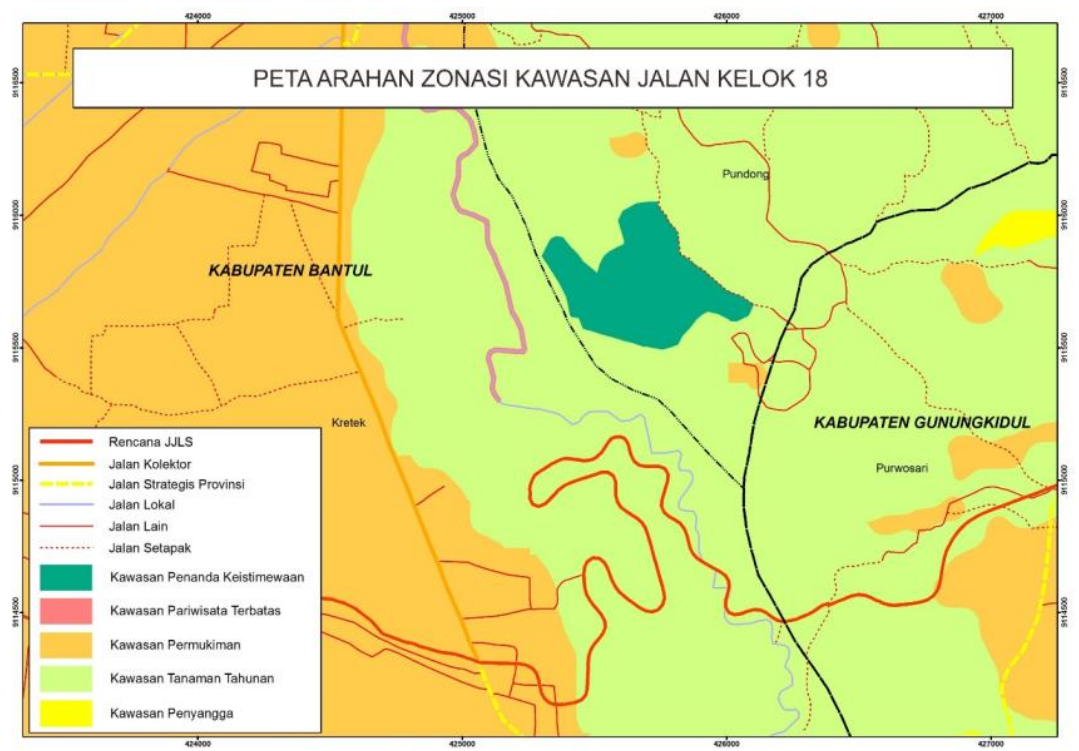

Gambar 5. Peta Arahan Zonasi Kawasan Jalan Kelok 18 Sumber : Analisis, 2017

Berdasarkan peta zonasi di atas, kawasan pariwisata terbatas yang berada di beberapa bagian jalan lokal yang berpotongan dengan jalan kelok 18 dapat digunakan untuk kawasan wisata terbatas. Kawasan ini telah populer sebagai Kawasan Watu Lumbung yang didalamnya yang juga sebagai lokasi untuk menikmati Kawasan Parangtritis dari atas bukit. Wisata terbatas yang diperbolehkan dalam kawasan ini adalah pariwisata tanpa adanya bangunan skala besar karena kawasan ini terletak pada topografi yang curam. Wisata yang diperbolehkan adalah kegiatan wisata alam non masal dengan pengunjung yang tidak banyak karena akses jalan yang tidak bisa diakses oleh bus. Pengembangan wisata yang dimungkinkan adalah warung semi permanen yang juga berfungsi sebagai gardu pandang untuk melihat pemandangan Kawasan Parangtritis dan sekitarnya. Namun pengembangan wisata ini adalah wisata bersyarat yaitu dengan memperhatikan topografi sehingga bangunan yang dibangun sebagai pendukung wisata dibangun dengan standar keamanan yang baik. Persyaratan lainnya adanya ancaman bencana gempa bumi dan tanah longsor sehingga pengelola tempat wisata telah melakukan upaya-upaya mitigasi bencana. Selain itu juga 


\section{Bagus Ramadhan, Strategi Pengendalian Pemanfaatan Lahan di Kawasan Jalan Kelok 18 Ruas Parangtritis - Girijati}

diperlukannya batasan-batasan pembangunan yaitu dengan meminimalkan bangunan untuk mengendalikan pembangunan di kawasan dengan topografi agak curam yaitu dengan memperbolehkan membangun maksimal 10 meter di kiri kanan jalan. Hal ini dikarenakan apabila lebih dari 10 meter dikhawatirkan akan terjadi pelebaran pemanfaatan lahan menuju kawasan lainnya yaitu kawasan yang diperuntukan sebagai kawasan tanaman tahunan. Adanya ruang untuk warungwarung di kawasan ini juga sebagai wadah untuk mengantisipasi adanya warungwarung di sepanjang jalan kelok 18 karena jalan kelok 18 adalah jalan nasional yang perlu untuk meminimalkan hambatan di kiri dan kanan jalan.

Selain kawasan pariwisata terbatas terdapat pula kawasan pariwisata penanda keistimewaan di dekat jalan kelok 18. Kawasan ini merupakan kawasan terpadu yang memang sudah direncanakan sebagai penanda keistimewaan. Kawasan ini direncanakan mampu untuk menampung berbagai kegiatan, mulai kegiatan edukasi, pariwisata, budaya dan kegiatan lainnya. Pengendalian yang perlu dilakukan adalah pada kawasan sekitarnya. Dengan adanya destinasi baru yang dapat menarik banyak pengunjung, harapannya kawasan sekitarnya tetap menjadi kawasan non terbangun karena kondisi topografi dan ancaman bencana longsor dan gempa bumi. Yang perlu diperhatikan adalah mengenai aksesibilitas menuju kawasan terpadu penanda keistimewaan. Aksesibilitas terbaik untuk kawasan ini adalah menggunakan aksesibilitas eksisting dari sisi utara melalui Jalan Parangtritis-Siluk. Sebenarnya kawasan ini dapat membangun jalan baru yang menyambung dengan Jalur Jalan Lintas Selatan (JJLS), namun apabila jalur ini dibangun maka perlu pengendalian pemanfaatan lahan di kiri kanan jalan, sehingga pada saat ini kawasan penanda keistimewaan lebih baik menggunakan akses eksisting melalui Jalan Parangtritis-Siluk atau dari sisi utara.

Kawasan lainnya adalah kawasan tanaman tahunan menyesuaikan hasil dari analisis kesesuain lahan bahwa kawasan tersebut sesuai untuk kawasan tanaman tahunan. Sebagian besar kawasan ini adalah kawasan yang didominasi oleh topografi agak curam dan berada pada kawasan rawan bencana gempa bumi dan tanah longsor sehingga idealnya kawasan ini memang sebagai kawasan budidaya namun budidaya yang juga sebagai sarana mitigasi tanah longsor yaitu dengan menggunakannya sebagai budidaya tanaman tahunan. Kawasan tanaman tahunan ini tidak diperbolehkan untuk kegiatan terbangun dan pemanfaatannya terbatas hanya untuk kegiatan budidaya tanaman tahunan sehingga kawasan di kiri kanan jalan kelok 18 yang ditetapkan sebagai kawasan tanaman tahunan juga harus steiril dari bangunan. Khusus untuk kiri kanan jalan kelok 18 terdapat beberapa pertimbangan yaitu status jalan sebagai jalan nasional sehingga kegiatan seperti permukiman dan perdagangan dan jasa yang berorientasi langsung di kiri dan kanan jalan diminimalkan untuk menghindari hambatan keluar masuk kendaraan. Selain itu alignment jalan kelok 18 yang berkelok dan menanjak membutuhkan konsentrasi yang lebih bagi pengendara sehingga keluar masuk kendaraan dari pemanfaatan lahan di kiri kanan jalan kelok 18 seharusnya diminimalisir. Pertimbangan lainnya adalah kawasan sekitar jalan kelok 18 telah memberikan ruang untuk pemanfaatan-pemanfaatan lainnya yaitu kawasan permukiman di sebelah barat jalan kelok 18, wisata terbatas di kawasan sekitar Watu Lumbung untuk warung-warung sekaligus lokasi melihat Kawasan Parangtritis dari atas 


\section{Bagus Ramadhan, Strategi Pengendalian Pemanfaatan Lahan di Kawasan Jalan Kelok 18 Ruas Parangtritis - Girijati}

bukit, dan kawasan wisata terpadu di Kawasan Terpadu Penanda Keistimewaan Parangtritis. Dengan telah terwadahinya pemanfaatan lahan lain di sekitar jalan kelok 18 seharusnya pada jalan kelok 18 dapat lebih steiril dari pemanfaatan lahan terbangun.

\section{Disinsentif di Kawasan Jalan Kelok 18}

Selain dengan arahan zonasi, pengendalian di kawasan jalan kelok 18 dapat dengan mekanisme disinsentif. Menurut Permendagri Nomor 115 Tahun 2017 tentang Mekanisme Pengendalian Pemanfaatan Ruang Daerah, disinsentif adalah perangkat untuk mencegah, membatasi pertumbuhan atau mengurangi kegiatan yang tidak sejalan dengan kawasan yang ditetapkan oleh rencana tata ruang.

Dalam penetapan disinsentif perlu untuk mengidentifikasi zona, isu dan sasaran pemberian disinsentif. Pada penelitian ini zona yang disasar dalam pemberian disinsentif adalah kawasan sekitar jalan kelok 18, namun utamanya adalah kiri kanan jalan kelok 18. Sedangkan isu yang kemungkinan dihadapi adalah timbulnya bangunan warung-warung karena kawasan tersebut berada pada kawasan wisata Parangtritis dan memberikan panorama kawasan Parangtritis dari atas bukit. Selain itu kawasan ini juga mempunyai tingkat kelerengan agak curam dan ancaman bencana tanah longsor dan gempa bumi. Sehingga sasaran pengenaan disinsentif adalah untuk mencegah timbulnya warung-warung yang berada di kiri kanan jalan kelok 18. Berdasarkan identifikasi isu tersebut maka kebijakan disinsentif yang dapat direkomendasikan yaitu pembatasan infrastruktur bagi bangunan liar yang tetap berdiri di kiri kanan jalan kelok 18 seperti listrik dan air bersih dan pembangunan batas fisik baik berupa struktur yaitu pagar pembatas maupun vegetasi sebagai pembatas kiri kanan jalan kelok 18.

\section{KESIMPULAN DAN SARAN}

Dalam arahan zonasi, kawasan di kiri kanan jalan kelok 18 ditetapkan sebagai kawasan budidaya tanaman tahunan. Berdasarkan analisis kesesuaian lahan, budidaya tanaman tahunan merupakan penggunaan lahan yang paling sesuai pada kawasan ini. Selain itu dengan adanya ancaman bencana gempa bumi dan tanah longsor kawasan ini seharusnya menjadi kawasan budidaya non terbangun. Selanjutnya dalam zoning text kawasan budidaya tanaman tahunan tidak diperkenankan adanya kegiatan budidaya terbangun karena memperhatikan kelerengan dan ancaman bencana yang ada.

Selain berdasarkan peraturan zonasi, pengendalian pemanfaatan lahan jalan kelok 18 juga dapat dilakukan dengan penetapan disinsentif. Penetapan disinsentif perlu untuk mengidentifikasi zona, isu dan sasaran. Dengan pertimbangan tersebut maka disinsentif yang dapat dilakukan pada jalan kelok 18 ini adalah sebagai berikut :

1. Pembatasan infrastruktur pendukung kegiatan pariwisata seperti listrik dan air bersih pada bangunan liar di kiri kanan jalan kelok 18 sehingga penggunaan lahan di kiri kanan jalan kelok 18 yang berbatasan langsung tidak dilayani oleh listrik dan air bersih.

2. Pembangunan batas fisik baik berupa struktur yaitu pagar pembatas maupun vegetasi sebagai pembatas kiri kanan jalan kelok 18. 


\section{Bagus Ramadhan, Strategi Pengendalian Pemanfaatan Lahan di Kawasan Jalan Kelok 18 Ruas Parangtritis - Girijati}

Pemangku kepentingan tata ruang kedepannya akan menghadapi dilema yang sama dengan kawasan Bukit Bintang apabila perencanaan kawasan dan pengendalian kawasan sekitar jalan kelok 18 belum diantisipasi. Kawasan sekitar jalan kelok 18 yang berada pada kawasan wisata akan berkembang pesat apabila belum ada mekanisme pengendalian pemanfaatan lahan yang dilakukan. Berdasarkan uraian yang telah ada, maka saran bagi pemangku kepentingan tata ruang baik di tingkat Pemda DIY maupun Pemkab Bantul adalah sebagai berikut :

1. Perlu untuk segera mengesahkan Rencana Tata Ruang Kawasan Strategis Provinsi Pantai Sleatan dan Rencana Detail Tata Ruang Pantai Selatan Bantul sebagai pedoman dalam pengendalian pemanfaatan ruang.

2. Dalam kedua rencana tata ruang tersebut, arahan pada kawasan sekitar jalan kelok 18 adalah bebas dari bangunan dan kegiatan budidaya dan mengutamakan kelancaran kegiatan lalu lintas di jalan kelok 18.

3. Antisipasi penggunaan lahan di sekitar jalan kelok 18 yaitu munculnya warung-warung seperti yang terjadi di sekitar kawasan Bukit Bintang dengan memberikan wadah bagi warung-warung tersebut di sekitar kawasan Watu Lumbung dengan memperhatikan kelerengan dan ancaman bencana gempa bumi dan tanah longsor.

\section{DAFTAR PUSTAKA}

Badan Nasional Penanggulangan Bencana, 2016. Kajian resiko bencana Indonesia. Jakarta : BNPB

Darmawidjaja, M. I. 1974. Dasar-dasar klasifikasi tanah. Yogyakarta : Penerbit Diktat UGM "Dwitunggal".

Dinas Pariwisata DIY, 2017. Masterplan pengembangan kawasan terpadu penanda keistimewaan DIY. Yogyakarta : Dinas Pariwisata DIY

Dinas Pertanahan dan Tata Ruang Kabupaten Bantul, 2017. Rencana detail tata ruang pantai selatan Kabupaten Bantul. Bantul : Dinas Pertanahan dan Tata Ruang Kabupaten Bantul

Hall, P., \& Tewdwr-Jones, M. 2010. Urban and regional planning. London : Routledge.

Hardjowigeno, S. 2007. Evaluasi kesesuaian lahan dan perancangan tataguna lahan. Yogyakarta : Gadjah Mada University Press.

Peraturan Menteri Agraria dan Tata Ruang Nomor 37 Tahun 2016 Tentang pedoman penyusunan kawasan strategis provinsi dan kawasan strategis kabupaten. Jakarta : Kementerian Agraria dan Tata Ruang.

Peraturan Menteri Dalam Negeri Nomor 115 Tahun 2017 Tentang mekanisme pengendalian pemanfaatan ruang daerah. Jakarta : Kementerian Dalam Negeri

Peraturan Menteri Pekerjaan Umum Nomor 20 Tahun 2011 Tentang pedoman penyusunan rencana detail tata ruang. Jakarta : Kementerian Pekerjaan Umum.

Peraturan Menteri Pertanian Nomor. 837 Tahun 1980 Tentang kriteria dan tata cara penetapan kawasan hutan lindung. Jakarta : Kementerian Pertanian.

Yin, J. 2012. Urban planning for dummies. Ontario : John Wiley \& Sons. 